\title{
ECUATIA CASEI
}

\section{Atmosfere locuibile/}

\section{THE EQUATION OF THE HOUSE}

\section{Habitable Atmospheres}

Andrés ROS CAMPOS, lect. dr. arh./ lect. PhD. arch.

Universitatea Cardenal Herrera-CEU, CEU Universities, Valencia, Spania/

Cardenal Herrera University-CEU, CEU Universities, Valencia, Spain

\section{Rezumat}

În anii 1920 arhitecţii şi-au pus problema asupra modului în care ar trebui să fie locuirea în viaţa modernă. Problema a fost discutată în cadrul Congreselor de Arhitectură Modernă şi mai ales în anul 1929 la a doua ediţie a CIAM ţinută la Frankfurt, sub titlul existenzminimum, care explora posibilităţile locuirii minimale, propunând noi modele de viaţă. Mai târziu, după distrugerile generate de cel de-al doilea război mondial, problema avea legătură mai ales cu optimizarea

\begin{abstract}
In the twenties of the $20^{\text {th }}$ century, architects experimented with the dilemma of what housing should be for modern life. The issue was discussed in The Modern Architecture Congresses and especially in 1929 in the second edition of CIAM held in Frankfurt, with the title existenzminimum that explored the possibilities of minimal housing, proposing new models of living. Later, after the destruction of the Second World War, the problem was located in the optimization of the domestic
\end{abstract}


spaţiului domestic şi cu standardizarea construcţiilor, care ar fi putut rezolva problema lipsei spaţiilor locuibile.

Mişcarea Modernă a definit bazele acestei preocupări domestice transgresând obiceiurile antice, prin explorarea abstractizării şi eliminarea a tot ceea ce este superfluu, fapt care care contrastează cu obiceiul utilizatorilor de a adăuga elemente exterioare în spațiul arhitectural. Am putea explica design-ul casei ca pe o ecuaţie compusă prin adiţia unor parametri precum: casa, mobilarea, utilizatorii şi posesiunile acestora. Arhitectul domină atât conformaţia casei cât şi mobilierul. Apărarea lui Adolf Loos a „designului complet" care l-a împiedicat pe locuitor să introducă ceva fără supravegherea arhitectului pare utopică și excesivă. Rezistența și obstrucția utilizatorului este o interferență imposibil de eliminat.

Unii arhitecți au dezvoltat arhetipuri de moduri de viață noi în proiectarea caselor lor. Acest text ridică problema acestei ecuații în care arhitectul încearcă să minimalizeze elementele care distorsionează percepția spațiului domestic care explorează un anumit concept experimental.

\section{Cuvinte cheie/ Keywords}

arhitectură, acasă, casă, domestic, abstracţiune/

architecture, home, house, domestic, abstraction

\section{Atmosfera locuibilă}

Dacă am vrea să descompunem procesul de proiectare a unui spaţiu domestic, casa, şi am putea să îl reducem la o ecuaţie, parametrii acesteia ar fi space and the standardised construction that would solve the lack of housing.

The Modern Movement defined the foundations of this domestic restlessness by transgressing ancient habits, exploring abstraction, and eliminating the superfluous, which contrasts with the habit of the users of adding alien elements to the architectural space. We could explain the design of the home as an equation formed by the addition of parameters such as; the house, the furniture, the users and their belongings. The architect has mastery over the design of the house and as much about the furniture. The defence of Adolf Loos of the "complete design" that prevented the inhabitant from introducing anything without the supervision of the architect seems utopian and excessive. The resistance and the obstruction of the user is an interference impossible to eliminate.

Some architects have developed archetypes of new ways of life in their design of houses. This text raises a thought about this equation where the architect tries to minimize the elements that distort the perception of the domestic space exploring a particular experimental concept.

\section{The habitable atmosphere}

If we wanted to decompose the design process of a domestic space, the house, and we were able to reduce it to an equation, the integral parameters of 
reprezentaţi de arhitectura casei plus mobilarea, plus utilizatorii, plus posesiunile acestora. Aşadar, ecuaţia s-ar constitui astfel:

$$
\text { Acasă = Casă + Mobilare + Oameni + Obiecte }
$$

Dificultatea care există în această ecuaţie constă nu neapărat în combinarea parametrilor ei, ci în acceptarea unora dintre aceştia. Arhitectul se confruntă cu o oarecare rezistenţă din partea publicului larg, spre acceptarea modificărilor substanțiale ale limbajului și aplicarea postulatelor moderne și contemporane în arhitectura sa. După cum a afirmat Ludwig Mies van der Rohe, arhitectura trebuie să fie o reflectare a timpului său (Schulze \& Windhorst, 2019). Totuși, această idee nu este întotdeauna acceptată de opinia publică și există o disociere între gustul arhitectului și gustul oamenilor.

Trebuie, de asemenea, să avem în considerare că spaţiul domestic are un grad de subiectivism. Pe de o parte regăsim creativitatea arhitectului, iar pe de altă parte abordarea utilitaristă a locuitorului. Articolul de faţă explorează câteva dintre aspectele subiective.

Aceasta este ceea ce arhitectul poate controla, iar nivelul de studiu și de definire a nuanțelor atmosferei locuibile va condiționa controlul asupra obiectelor personale. Aşa cum Adolf Loos declara, obiectele personale trebuie să fie în armonie cu spaţiul (Loos, 1993).

Peter Zumthor vorbeşte despre atmosfere şi nu îmi pot imagina un spaţiu arhitectural mai bun decât acela care serveşte drept refugiu omului. Ideii lui Le Corbusier despre "casa ca maşină de locuit"(Le Corbusier, 2007), Álvaro Siza îi adaugă noţiunea de "casă ca maşinările complexă... iar locuirea în casă it could be; the architecture of the house, plus the furniture, plus the users, plus their personal belongings. Thus, the equation would be stated in the following way:

Home $=$ House + Furniture + People + Things

The difficulty of this equation lies not in the combination of its parameters but in the acceptance of some of them. The architect faces some resistance from the general public, towards the acceptance of substantial changes in language and the application of modern and contemporary postulates in its architecture. As Ludwig Mies van der Rohe posited, architecture must be a reflection of its time (Schulze \& Windhorst, 2019). However, this idea is not always assumed by public opinion and there is a dissociation between the taste of the architect and the taste of the people.

We must also consider that domestic space has something subjective. On the one hand the creative mind of the architect and on the other hand the utilitarian mind of the inhabitant. This article identifies some of these subjectivities.

This is what the architect can control and the level of study and definition of the nuances of the habitable atmosphere will condition the control over the personal belongings. As Adolf Loos defended, personal objects must be in harmony with the space (Loos, 1993).

Peter Zumthor talks about atmospheres and I cannot imagine better architectural space to do it than the one that inhabits and serves as a refuge for man. For Le Corbusier's idea that "a house is a living machine" (Le Corbusier, 2007), Álvaro Siza adds that "a house is a complex machine ... living in a house is 
este un loc de muncă cu normă întreagă"(Cianchetta \& Molteni, 2004).

Intenţia acestei lucrări este de a stabili legătura dintre istorie şi arhitectura contemporană prin exemple ce ţin de unităţile rezidenţiale. Ne vom concentra atenţia asupra unor personalităţi ale scenei arhitecturale ale secolului al XIX-lea şi XX-lea şi vom face o paralelă cu arhitectura de astăzi. Fiecare personalitate ne va prezenta câte un concept.

Această clasificare este rezultatul lăsat de multe cărți și teorii comentate, citite și studiate timp de mai mult de 20 de ani. Locuirea a fost tema majoră a Mişcării Moderne și a fost centrul în jurul căruia sa rotit toată gândirea arhitecturală încă de la începutul secolului XX și a dezvoltat toate activitățile umane, așa cum au fost definite de Eames în 1944 (Eames \& Eames, 2015).

Istoria casei este istoria inteligenței, prin urmare, în această reflecție, includ referințe care, într-un fel sau altul, au influențat prin contribuția lor teoretică și reflexivă concepţia acestei clasificări.

Adolf Loos explora la începutul secolului al XX-lea aspectele psihologice ale spaţiului domestic şi nevoia de intimitate într-o casă introvertită. Pe de altă parte, Mies, la jumătatea aceluiaşi secol aduce în discuţie casa extravertită ca pe un experiment în jurul spaţiului flexibil şi articularea între sistemul structural şi cel spaţial, aşa cum reiese din comentariul lui Diaz, Serra şi Merí (2018).

Într-o altă discuţie recentă, Torres ilustrează nobila asemănare a casei cu palatul, la fel cum Le Corbusier a proiectat casa Hutheesing-Shodan în 1951 (Torres Cueco, 2008). a full-time job"(Cianchetta \& Molteni, 2004).

The intention of this paper is to establish a link between history and architectural contemporaneity through examples of residential units. Let us focus on some characters from the architectural scene from the 19th century to the 20th century and that will allow us to draw a parallelism with the current architecture. Each character will present us with a concept.

This classification is the result left by many books and theories commented, read and studied for more than 20 years. Because the house was the theme of the Modern Movement and was the centre around which all architectural thinking revolved since the early 20th century, and it developed all human activities as defined by the Eames in 1944 (Eames \& Eames, 2015).

The history of the house is the history of intelligence, therefore, in this reflection, I incorporate references that in one way or another have influenced with their theoretical and reflexive contribution on the conception of this classification.

If Adolf loos explored in the early $20^{\text {th }}$ century the psychological aspects of domestic space and the need for privacy in an introverted house. However, Mies, in the mid $20^{\text {th }}$ century, explores the extroverted house as an experiment around flexible space and the articulation between the structural system and the spatial system, as Diaz, Serra and Merí (2018) comment.

In another recent reflection, Torres illustrates the noble consideration of the house as a palace, just as Le Corbusier designed the Hutheesing-Shodan house in 1951 (Torres Cueco, 2008). 


\section{Arhitecturile subiective ale casei}

\section{Casa dinamică}

La începutul secolului XX, Antonio Gaudí a proiectat și construit un bloc de locuințe în bulevardul Gracia din Barcelona, Casa Milá, unul dintre cei mai importanţi exponenți ai stilului Art Nouveau. Casa Milà reprezenta o idee de avangardă pentru timpul său. Totuşi, ea s-a aflat în centrul criticilor şi al controverselor în ceea ce priveşte componenta ei estetică. În cadrul acestui proiect regăsim prima opoziţie a opiniei publice în faţa dezvoltării arhitecturii. În timpul construirii, proiectul a fost blocat de consiliul local şi Gaudi a avut de asemenea probleme cu beneficiarii, familia Mila, din cauza aspectelor economice, iar odată ce clădirea a fost finalizată, locuitorii Barcelonei se plângeau de aspectul casei, iar Gaudi era ridiculizat prin caricaturi. Oamenii denumeau clădirea în mod peiorativ "La Pedrera", ceea ce înseamnă "cariera", din cauza finisajelor şi a formelor sale sinuoase. Totuşi, clădirea este un exemplu de originalitate, ale cărei forme organice aduc dinamism spaţiului generat.

În paralel, regăsim un exemplu contemporan în care spaţiul dinamic este din nou predominant. Casa Gili (Fig. 1), proiectată în anii 1980 de arhitecţii José Antonio Martínez Lapeña şi Elías Torres. Casa este înţeleasă în zilele noastre, însă ea a fost creată întro perioadă în care era considerată bizară din cauza formei ei fragmentate ce face trimitere la arhitectura deconstructivistă. Deformarea planului şi direcţiile multiple care marchează pereţii ne fac să calificăm casa drept una amorfă. Forma care nu este recognoscibilă era controversată, fapt de unde decurge şi dinamismul spaţiului.

\section{Subjective architectures of the house}

The dynamic house

At the beginning of the $20^{\text {th }}$ century, Antonio Gaudí designed and built a block of flats in Gracia avenue in Barcelona, Casa Milá one of the greatest exponents of Art Nouveau. Milà house was an advanced idea to its time. However, it was the centre of criticism and controversial opinions about its aesthetics. In this project, we find our first resistance by public opinion to the advancement of architecture. During the construction, the project was paralysed by the city council and Gaudí also had problems with the promoters, the Mila family, due to economic issues and once the building was finished the people of Barcelona complained about the aesthetics of the project and Gaudi was ridiculed through cartoons. People ended up pejoratively calling the building "La Pedrera" which means the quarry, due to its finishes and its sinuous shapes. However, it is an example of originality and organic forms that bring dynamism to the generated space.

In parallel, we find a contemporary example where the dynamic space is also the protagonist. The Gili house (Fig. 1) designed in the 80s by the architects José Antonio Martínez Lapeña and Elías Torres. The house, created in a period in which from our days is understood but at the time generated strangeness for its fragmented forms of architectural Deconstructivism. The deformation of its plan and the multiple directions that mark the walls make us qualify the house as amorphous. The unrecognizable form was controversial, while the result is the dynamism of space. 


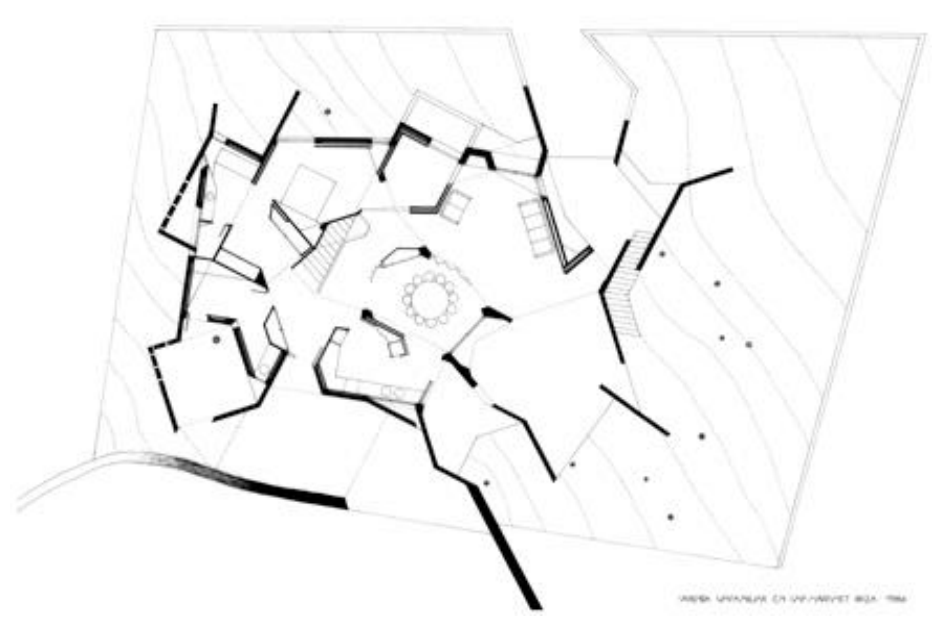

Fig. 1: Casa Gili. Architecţi/ Architects: José Antonio Martínez Lapeña \& Elías Torres. JAMLET. Santa Eulària des Riu, Ibiza, Spania/ Spain, 1987.

Sursa/Source: www.jamlet.net

\section{Casa introvertită}

Arhitectul britanic al secolului al XIX-lea, Sir John Soane (1753-1837) întruchipează excepţia de la maxima care susţine că arhitectul îndepărtează elemente în loc să adauge. În plină perioadă de influenţă neoclasică şi la apusul romantismului, Soane proiectează noua lui casă, cu intenţia de a o transforma în propriul muzeu, care să conţină colecţia sa de artă. Din exterior, nimic nu prevede bogăţia artistică ce este adăpostită înăuntru. Am putea spune că Soane este precursorul unei idei moderne, susţinută mai târziu de Adolf Loos. Interiorul casei aparţine utilizatorului, în timp ce exteriorul trebuie să transmită o anume sobrietate şi neutralitate oraşului.

Reflexia contemporană se regăseşte în casa Gaspar (Fig. 2) a lui Alberto Campo Baeza, unde exteriorul

\section{The introverted house}

The $19^{\text {th }}$ century British architect Sir John Soane (1753-1837) embodies an exception to the maxim that the architect removes elements instead of adding them. In full Neoclassical influence and in the dawn of Romanticism, Soane designed his new home with the intention of turning it into his museum, in order to house his art collection. From the outside, nothing presages the artistic wealth that is housed inside. We could say that Soane is the precursor of a Modern idea defended later by Adolf Loos. The house towards the interior belongs to the user, while towards the exterior it must transmit certain sobriety and neutrality towards the city.

The contemporary reflection is found in the Gaspar house (Fig. 2) by Alberto Campo Baeza, where the 
este sobru şi neutru. În mod absolut este reprezentată casa închisă în sine, timidă, discretă şi misterioasă, cu un puternic caracter abstract. Casa este rezolvată în plan printr-un pătrat cu latura de 18 metri şi cu înălţimea zidurilor de 3.5 metri. Acoperişul spaţiului central este mai înalt, atingând 4.5 metri, permiţând acestui volum să se ridice deasupra pereţilor perimetrali. Doua spaţii de tip patio contribuie la generarea unei zone exterioare private, care se conectează vizual cu interiorul prin intermediul deschiderilor de sticla cu dimensiuni de $2 \times 2$ metri. Aceste spatii contribuie la introvertirea spaţiului domestic. Din exterior, lipsa de comprehensiune a privitorului intră în contrast cu interiorul, care este bogat în conexiuni vizuale. A intra în această casă este ca despachetarea unui cadou. exterior is potentially sober and neutral. Absolutely abstract It represents the house enclosed in itself, shy, discreet and mysterious and with a strong abstract character. The house is solved in plan with a square of 18 meters side and with walls of 3.5 meters height. The roof of the central space is higher, reaching $4.5 \mathrm{~m}$ and allowing its volume to emerge over the perimeter walls. Two patios contribute to generating a private exterior space that connects visually with the interior through glass openings of $2 \times 2$ meters. The patios contribute to the introversion of the domestic space. From the outside, the incomprehension of the observer contrasts with the interior, rich in visual connections. Entering is like opening a gift.

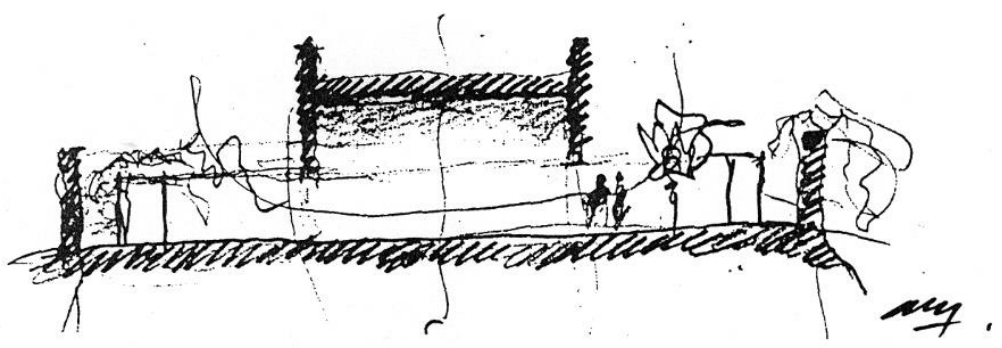

Fig. 2: Casa Gaspar. Alberto Campo Baeza. Vejer de la Frontera, Cádiz, Spain. 1990-92.

Desen de/ Drawing by Alberto Campo Baeza.

Sursa/Source: www.campobaeza.com/es/gaspar-house

\section{Casa extravertită}

Cunoaştem cu toţii povestea lui Ludwig Mies van Der Rohe şi a doamnei Farnsworth ca beneficiar, care I-a angajat pe Mies pentru a proiecta casa care urma să î poarte numele. Dar această înţelegere a fost obstrucţionată din cauza dezacordurilor în privinţa

\section{The extroverted house}

We are knowledgeable of the story of Ludwig Mies van Der Rohe and the consideration of Mrs Farnsworth as a patron who hired Mies for the design of the house that would bear her name. But this patronage became obstruction due to 
onorariului arhitectului, fapt ce a generat in final şi intervenţia instanţei. Ea a adus ca argument imposibilitatea de a locui în casă din cauza disconfortului adus de faţadele din sticlă, nu prin prisma expunerii vieţii private, ci din cauza dificultăţii de a menţine curățenia geamurilor în urma coliziunilor ţânţarilor cu suprafaţa vitrată, atraşi de lumina de la interior (Neumeyer, 2000). disagreements over the emoluments of the architect, which ended up in court. She used the argument of the impossibility of living in the house due to the discomfort of their glass facades, not by exposing the interior life but by the difficulty of keeping the glass clean due to the collisions of mosquitoes attracted by the interior lighting (Neumeyer, 2000).

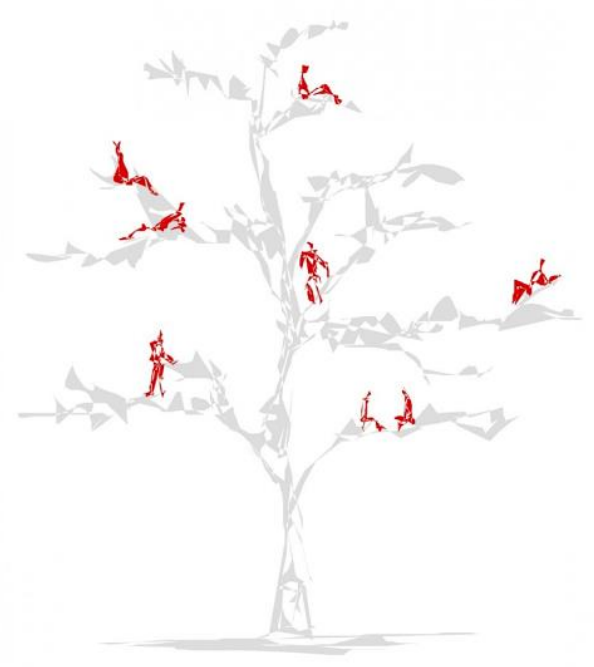

Fig. 3: Casa NA. Sou Fujimoto. Japonia. 2010. Casa de dezvoltă precum ramurile unui copac, producând o serie de spaţii care îşi expun locuitorii graţie trasnparenţei faţadei./

NA House. Sou Fujimoto. Japan. 2010. The house evolves like the branches of a tree producing a concatenation of spaces that exhibit its inhabitants thanks to the transparency of its facade.

Sursa/Source: www.plataformaarquitectura.cl/cl/02-155411/casa-na-sou-fujimoto

Putem crea un paralelism între caracterul extravertit al casei cu proiectul arhitectului japonez Sou Fujimoto, casa NA (Fig. 3) care constă în deschiderea casei spre exterior, datorită faţadei complet transparente. Structura din bare metalice vopsite
We can establish parallelism with this extroverted character of the house with the project of the Japanese architect Sou Fujimoto, the NA House (Fig. 3 ) that represents the opening of the house to the exterior, thanks to its completely transparent 
complet în alb este metafora care face trimitere la ideaa primitivă de locuire a copacilor. Proiectul este un exerciţiu de extroversiune între natură şi artificial, care arată existenţa interiorului. Urmărind ideea de locuire în copac, casa are 21 de niveluri diferite, conectate prin scări, ce generează o serie de platforme locuibile (Fujimoto, 2012).

\section{Casa evoluată (adaptată şi flexibilă)}

Primul proiect arhitectural al lui Le Corbusier (pe atunci cunoscut încă drept Charles-Edouard Jeanneret) a fost vila Jeanneret-Perret pentru părinţii săi, în 1912, urmărind un stil apropiat de Art Nouveau, realizată în localitatea La Chaux-de-Fonds, Elveţia. Proiectul era rezultatul tradiţiei arhitecturale a zonei, a inerţiei Conveţionalismului. Putem constata subiectivismul locuitorilor, care îl face pe Le Corbusier să includă mobilierul personal în amenajare, precum pianul mamei şi biroul tatălui, pe care îl înzestrează cu un spaţiu special. Casa se adaptează locuitorilor săi. După mai mulţi ani, Le Corbusier îşi demonstrează abilitatea de a evolua în linia limbajului modern, proiectând o nouă locuinţă pentru mama sa pe malul lacului Leman.

Exemplul contemporan de evoluţie şi adaptare începe cu un client care apelează la arhitectul Rem Koolhaas pentru a proiecta o casă în Bordeaux (Fig. 4). Totuşi, un accident I-a imobilizat pe client într-un scaun cu rotile şi astfel Koolhaas, condiţionat de noua realitate, a trebuit să revizuiască întregul proiect. Totuşi, această dificultate s-a transformat în calitatea noii case de a se adapta locuitorului său, Koolhaas realizând o casă la comandă. Circulaţiile erau foarte importante, mai ales cele verticale, ele constituind spaţiul cel mai important al casei, având façade. The structure of bars painted white is the metaphor that adapts to the primitive idea of inhabiting trees. The project is an exercise in extroversion between nature and artificiality, which shows the existence of its interior. To follow the idea of inhabiting the tree, the house has 21 different levels that are linked by stairs generating a sequence of habitable platforms (Fujimoto, 2012).

\section{The Evolved House (Adapted and Flexible)}

The first architectural project of Le Corbusier (Still as Charles-Edouard Jeanneret) was the villa JeanneretPerret for his parents in 1912, designed with a style close to Art Nouveau in La Chaux-de-Fonds, Switzerland. The project was the result of the architectural tradition of the place, the inertia of Conventionalism. We can appreciate it the subjectivity of the inhabitants, which makes Le Corbusier include personal furniture in the design, such as his mother's piano or his father's desk, which he endows with a special space. The house adapts to its inhabitants. Years later, Le Corbusier demonstrated his ability to evolve into Modern language by designing a new home for his mother on Lake Leman.

Our Contemporary example of evolution and adaptation begins with the commissioning of a client for architect Rem Koolhaas to design a house in Bordeaux (Fig. 4). However, an accident forced the client to remain in a wheelchair, and Koolhaas was conditioned by the new reality, the idea had to be redesigned. Nevertheless, the new difficulties become a virtue and the new house would adapt to its user. Koolhaas would make a custom house. The circulations would be important, especially the vertical circulation becomes the most important 
un lift hidraulic ce face legătura între niveluri. Această platformă în mişcare oferă posibilitatea a puncte de vedere distincte. Faţadele sunt rezolvate cu perforaţii la înălţimi diferite, adaptate la înălţimea scaunului rulant, pentru a permite acces vizual către exterior. Rezultatul este un obiect locuibil foarte puternic şi abstractizat. space in the house having a hydraulic lift that makes it possible to go through the different levels. This platform movement is allowing different points of view. The facades are resolved with perforations at different heights adapted to the height of the wheelchair in order to allow external vision. The result is a habitable, powerfully abstract artefact.

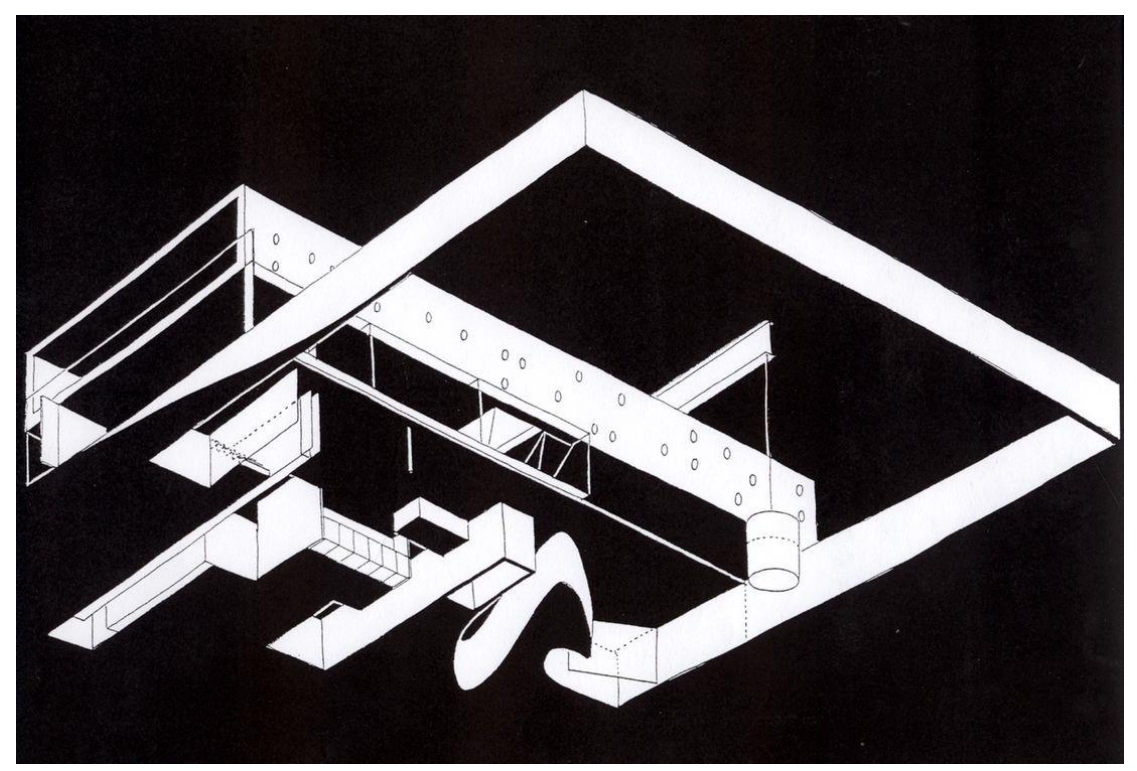

Fig. 4: Casa în Bordeaux/ House in Bordeaux. Rem Koolhaas. Bordeaux, Franţa/France. 1996-98. Sursa/Source: oma.eu/projects/maison-a-bordeaux

\section{Casa primitivă}

Carlo Scarpa (1906-1978), arhitectul veneţian, a creat în anii 1970 o casă pe jumătate îngropată, protejată, ascunsă şi integrată în peisaj, profitând de panta terenului pe care clientul îl propunea. Astfel, casa Ottolenghi are un acces prin intermediul unor scări care coboară printr-un coridor excavat. De la
The primitive house

Carlo Scarpa (1906-1978), Venetian architect, created in the 70 s of the $20^{\text {th }}$ century a house halfburied, protected, hidden and integrated into the landscape, taking advantage of a slope of the plot that customers had proposed. So, the Ottolengui house resolved access through stairs that 
intrarea de sus, de la stradă, scara descinde pe pasajul îngust și îngropat menționat mai sus, așa cum se observă în desenele originale ale arhitectului (Tommasi, Scarpa \& Guccione, 2012).

Această idee a casei ne aminteşte de concepţia lui Sou Fujimoto de locuire şi trimite la conceptul locuirii primitive într-o dublă interpretare. Pe de o parte, casa care îl obligă pe om să se adapteze (peştera) şi pe de altă parte, casa pe care oamenii şio construiesc, pe care o compun conform nevoilor lor, ca pe o mănuşă, ca pe un costum realizat la comandă (cuibul) (Foujimoto, 2012). descended to an excavated corridor. From the upper entrance, on the road, the stair descends to the aforementioned narrow and buried passage as it is observed in the original drawings of the architect (Tommasi, Scarpa \& Guccione, 2012).

This idea of a house reminds us of the thoughts of Sou Fujimoto on living and his references to the concept of primitive living in a double interpretation. On the one hand, the house that forces the human to adapt to it (the cave) and on the other, the house that the humans build to adapt to their needs, like a glove, like a custom-made suit (the nest) (Foujimoto, 2012).

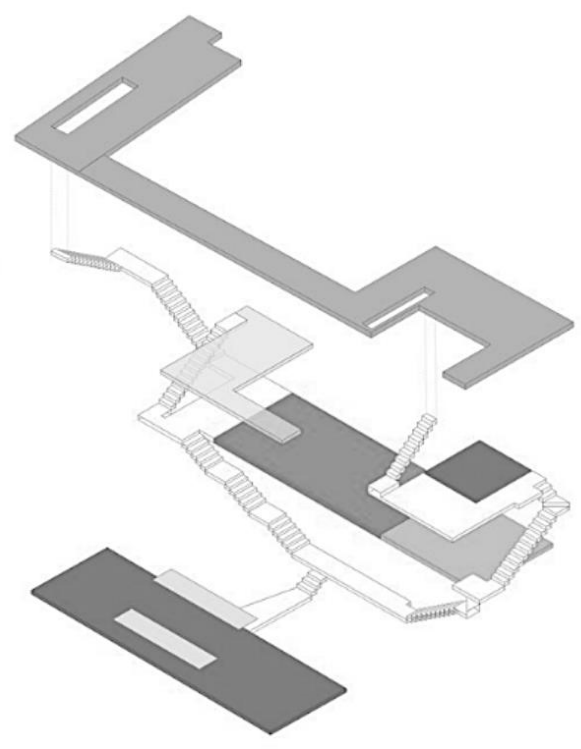

Fig. 5: Casa en la ladera. Casa de pe deal. Otura, Granada, Spania. 2002-2006. Schemă spaţială axonometrică./ Casa en la ladera. House on the hillside. Otura, Granada, Spain. 2002-2006. Spatial scheme in axonometric view. Sursa/Source: www.juandomingosantos.com/Juan_Domingo_Santos/CasaLaderaFotos.html\#14 
Ideea casei cuib şi a casei peşteră aduce în discuţie o altă casă din Spania proiectată de arhitectul Juan Domingo Santos (1961). O casă peşteră şi în acelaşi timp un labirint îngropat care generează refugiul perfect în Granada. Două pavilioane aflate la niveluri diferite, care sunt conectate printr-un coridor îngropat. Zonele sunt separate, cele de zi şi cele de noapte. Finisajele interioare sunt realizate din beton aparent, rugos, care este tencuit doar pe suprafeţele pe care cade lumina directă. Fereastra lungă din camera de zi este singura deschidere către exterior.

\section{Casa manifest}

Unul dintre cele mai interesante cupluri din istoria arhitecturii, Theo şi Nelly van Doesburg au contribuit prin lucrările lor la definirea manifestului mişcării Stijl (Conrads, 1971). Un manifest este un document în care se expirmă conturarea unei doctrine, propunere sau program. Dar manifestul Stijl a avut şi o formă construită, reprezentată de casa Schroeder a lui Gerrit Rietveld (Mulder, van Zijl \&. Rietveld, 1999).

Exemplul nostru contemporan, casa Garau Agusti (Fig. 6) a fost proiectată în anii 1980 de Enric Miralles şi Carme Pinós, care au constituit cel mai talentat cuplu de arhitecţi din Spania anilor 1990. În special, dezvoltarea acestei case dezvăluie trăsături deconstructiviste. Forma participă la o descompunere radială a planului, deschizând spații în unghiuri diferite. Totuşi, cel mai mare interes pentru arhitecţi a fost reprezentat de faţadă, ei fiind preocupaţi mai ales de prezentarea casei prin intermediul faţadei fragmentate. Propunerea manifestului susţine că spaţiul domestic este generat de fragmentarea elevaţiei (Mirales \& Pinós, 1991).
This idea of a nest house and cave house refers us to another house in Spain designed by the architect Juan Domingo Santos (1961). A cave house and at the same time buried labyrinth that generates the perfect refuge in Granada. Two pavilions located at different levels are connected by a buried corridor. The zones are thus separated in the day and night ones. The interior finishes are rough exposed concrete only plastered in the areas of direct lighting. The long window in the living room is the only opening to the outside.

\section{The manifesto house}

One of the most interesting couples in the history of architecture, Theo and Nelly van Doesburg contributed their work to defining Stijl manifesto (Conrads, 1971). A manifesto is a document in which a declaration of doctrines, proposals and programs are expressed. But Stijl manifesto also takes built form through the Schroeder house of Gerrit Rietveld (Mulder, van Zijl \&. Rietveld, 1999).

Our contemporary example, the Garau Agustí house (Fig. 6) was designed in the 80 s by Enric Miralles and Carme Pinós, who constituted the most talented couple of architects in Spain in the 90s. In particular, the generation of this housing lets glimpses Deconstructivist aspects. The form attends to a radial decomposition of the plan, opening spaces in different angles. However, the greatest interest for the architects resided in the façade, so they are concerned with representing the house as a model only of its fragmented façade. The manifest proposal is that the domestic space is generated from the fragmentation of the elevation (Mirales \& Pinós, 1991). 


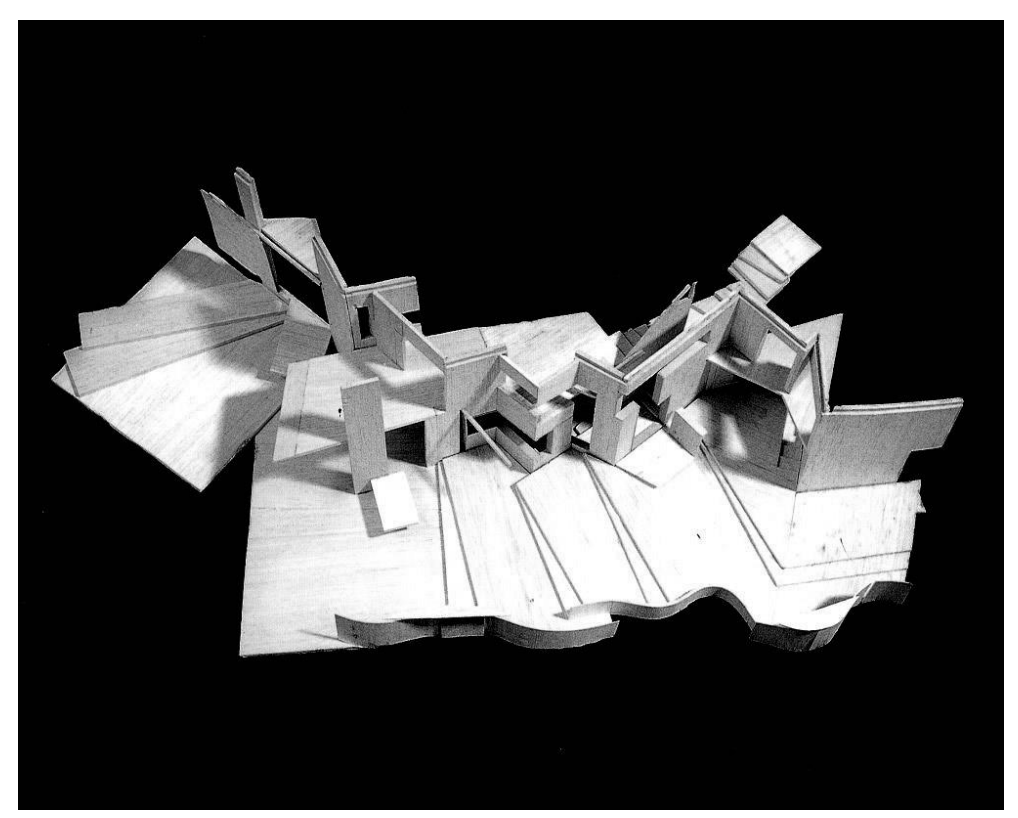

Fig. 6: Enric Miralles şi/and Carmen Pinós. Bellaterra, Barcelona, Spania/Spain, 1985. Sursa/Source: www.urbipedia.org/hoja/Casa_Garau_Agust\%C3\%AD

\section{Casa reper}

Analizând proiectul casei Ugalde realizată în 1952 de José Antonio Coderch, constatăm că lecţia arhitectului rezidă în dialogul său cu mediul. La începutul proiectului, Coderch consemnează situaţia fiecărui copac de pe lot şi proiectează casa respectând şi adaptând forma organică în jurul acestora. O altă condiţie impusă de proiect este reprezentată de panorama către mare. Culoarea albă a casei contribuie la perceperea sa omogenă pe fundalul cerului. Aşadar, peisajul este un punct de pornire puternic pentru proiect (Torres Cueco, 2009).
The landmark house

Focusing on the project of the Ugalde house in 1952 by José Antonio Coderch, we detected that the lesson of the architect lies in his dialogue with the environment. At the beginning of the project, Coderch draws the situation of each tree of the plot and will design the house respecting and adapting the organic form around them. The other condition of the design would be the views of the sea. The white colour of the house contributes to the perception of the same on the background of the sky. Therefore, the landscape is a very powerful starting condition for this project (Torres Cueco, 2009). 
Corespondentul contemporan al acestui tip de proiect poate fi regăsit într-una dintre propunerile bioului RCR din Olot, realizată în 2007. Casa rurală (Fig. 7) este localizată pe un lot care conţine şi o zonă cu o diferenţă de nivel mai mare de 10 metri (RCR arquitects, 2007). Tocmai în acest punct arhitecţii au ales să amplaseze casa. Conformaţia ei se bazează pe module care se citesc din exterior ca o succesiune de volume. Ei propun un contrast între materialul ales, oţelul cor-ten şi peisajul verde în care se inserează obiectul. în acest caz, ideea se compune în jurul relaţiei dintre casă şi peisaj (RCR arquitects, 2017).
Its contemporary parallelism is found in one of the projects of the RCR study in Olot in 2007. The rural house (Fig. 7) is located on a plot with a height difference of more than $10 \mathrm{~m}$ (RCR arquitects, 2007). It is precisely at this level where the architects insert the house. The design is based on modules that manifest to the exterior as several volumes. They propose a contrast between the chosen material, cor-ten steel, and the green landscape of the location. In this case, the idea resides in the relationship between the house and the landscape (RCR arquitects, 2017).

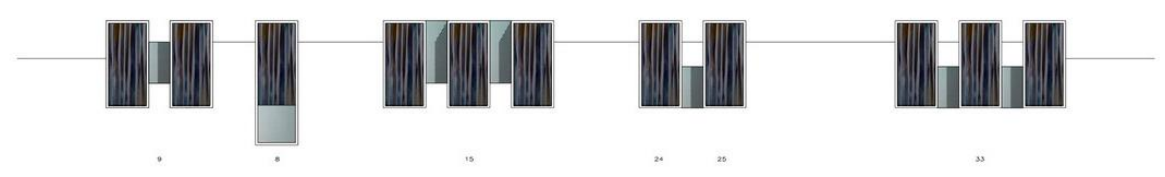

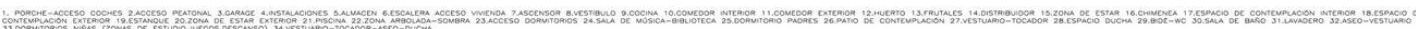

Fig. 7: Casa Rurală/Rural House. RCR Arquitectes. Girona, Spania/Spain 2004-2007.

El Croquis No.138. RCR Arquitectes. Madrid: El Croquis Editorial, 2007

\section{Casa spaţială}

Ca o ultimă idee, îmi amintesc de studiile lui Louis Isadore Kahn (1901-1974) în jurul castelelor scoţiene, care constau în dezvoltarea de spaţii în interiorul zidurilor groase ale acestora. Turnul Comlongon de secol XV din Clarencefield, în Scoţia şi probabil secţiunea Pantheonului din Roma I-au inspirat pe Kahn să exploreze această direcţie. Conceptul rezidă în curăţarea spaţiului central în urma unei operaţii centrifuge, care permite mutarea
The spatial house

As a last idea, I remember the studies of Louis Isadore Kahn (1901-1974) around the Scottish castles, which suggest the generation of spaces inside their thick walls. The $15^{\text {th }}$ century Comlongon tower, in Clarencefield, Scotland, and probably the section of the Pantheon in Rome inspired Khan in the use of this idea. The concept consists of cleaning the central space after a centrifugal operation that allows moving the closed spaces to the perimeter. 
spaţiilor închise pe perimetru. Acest principiu s-a reflectat în Prima Biserică Unitariană din Rochester (1962, 1969).

Un proiect contemporan care ar putea fi legat de această concepţie este casa Poli (Fig. 8), a lui Pezo von Ellrichshausen. Casa Poli are un zid de faţadă dublu, care integrează casa scării şi conectează diferitele niveluri, eliberând centrul spaţiului. Procedura permite crearea unui spaţiu mai amplu şi mai flexibil în interiorul casei. Este, aşadar, un exerciţiu spaţial.
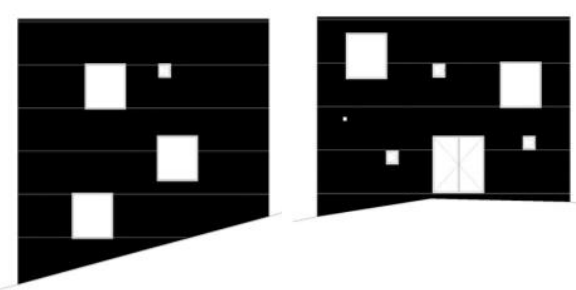

\begin{tabular}{llllll}
0 & 1 & 1 & 1 & 1 & 5 \\
\hline & & & &
\end{tabular}
This was reflected in the First Unitarian Church of Rochester (1962, 1969)

A contemporary project that could be linked to this idea is the Poli house (Fig. 8) by Pezo von Ellrichshausen. The Poli house has a double wall on the facade that integrates the staircases that connect the different levels, freeing the centre of the space. This operation allows for generating a wider and more flexible space in the house. It is, therefore, a spatial exercise.
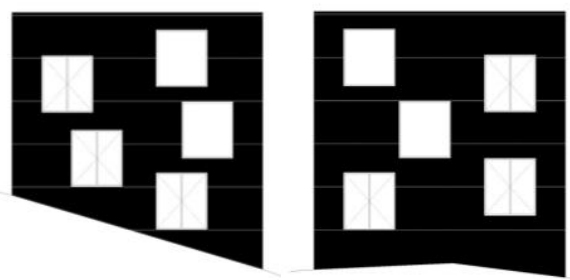

Fig. 8: Casa Poli, Elevaţii de nord, sud, est, vest./ Casa Poli. South, East, North and West elevations. Arhitecţi/Architects: Mauricio Pezo - Sofía von Ellrichshausen. Concepción. Chile. 2005.

Sursa/Source: pezo.cl
Această clasificare este rezultatul preocupării pentru explorarea varietăţii registrelor spaţiului domestic în raport cu varietatea utilizatorilor. Astfel, ea nu este conclusivă, dat fiind că există atât de multe tipuri de case şi de ocupanţi. Este rezultatul unei metode de cercetare aditivă și comparativă printre mai multe opinii ale mai multor autori într-o perioadă îndelungată de timp.
This classification is the result of the concern of manifesting the variety of records of the domestic space while there is a variety of users. It is therefore not conclusive as there are so many types of houses as types of users. It is the result of an additive and comparative researching method among several opinions of several authors over an extended period of time. 


\section{Concluzii}

Activitatea arhitectului este fundamentală pentru rezultatul ecuaţiei casei. Priceperea lui va influenţa natura spaţiului creat, percepţia lui, atmosfera creată, starea de spirit a locuitorilor, ușurința cu care viața se dezvoltă în interior. Arhitectul este capabil să transforme casa într-un cămin, dar nu o va face prin procurarea de obiecte personale, aşa cum o fac locuitorii, ci prin crearea unei atmosfere habitabile. În acest fel, arhitectul va face ca mobila să pară uneori izolată, alteori să fie integrată în arhitectură.

Aceste concepte au suficientă forţă ca să devină protagonistele unui proiect de arhitectură. Ele pot există independent şi autonom. Totuşi, acestea se pot de asemenea combina, într-un exerciţiu intelectual complex, în care este necesar să prevaleze un limbaj abstract clar şi rafinat. Atunci când ideea este puternică într-un proiect de arhitectură, nu este necesară forţarea limbajului sau exagerarea unor elemente constructive ori structurale.

Casa este subiectivă din două puncte de vedere. Ea devine un cămin transmiţând calităţile subiective ale arhitectului, care se reflectă în spaţiul arhitectural, precum şi pe cele ale utilizatorului, prin modul lui de locuire. Contribuţia arhitectului uneori conduce la dualităţi precum: dinamic şi static, introvertit şi extravertit, primitiv şi contemporan şi altele.

Aceste concepte pot fi combinate, generând spaţiul de locuit. Astfel toate aceste viziuni devin manifeste ale arhitecturii experimentale. Toate propun o reflecţie. Rezultatul este conturarea de propuneri

\section{Conclusions}

The work of the architect is fundamental for the result of the equation of the house. His dexterity will affect the nature of the created space, the perception of it, the atmosphere generated, the state of mind of its inhabitants, the ease with which life develops inside. The architect is capable of transforming a house into a home, but he will not do so by providing personal objects, as the inhabitant would do, but by generating a habitable atmosphere. In this way, the architect will make the furniture appear sometimes isolated, sometimes integrated into the architecture itself.

These concepts, have enough proactive force to be the protagonists of an architecture project. They can therefore exist independent and autonomous. However, they can also be combined, in a complex intellectual exercise in which a clear, refined and abstract language must prevail. When the idea is powerful in an architectural project, it is not necessary to force the language or make any constructive or structural boasting.

The house is subjective from a double point of view. It becomes a home transmitting the subjective qualities of the architect, reflected in the architectural space and the user, reflected in the ways of living. The contribution of the architect sometimes suggests duplicities such as; dynamic and static, introverted and extroverted, or primitive and contemporary among other concepts.

These concepts can be combined generating the living space. In this way all these visions are manifestos of experimental architecture. All propose a reflection. The consequence is the 


\section{Referinţe/ References}

Cianchetta, Alessandra \& Molteni, Enrico (2004), Álvaro Siza: Casas, 1954-2004. Editorial Gustavo Gili. Conrads, Ulrich (1971), Programs and Manifestoes on 20th-century Architecture. MIT Press.

Díaz Segura, Alfonso; Serra Soriano,Bartolomé, and Merí de la Maza Ricardo (2018), Space, Shape and Structure in the 50x50' House by Mies van der Rohe. VLC arquitectura Vol. 5, Issue 2 (October 2018): 175-202. Valencia: Universitat Politècnica de València.

Eames, Charles and Eames, Ray (2015) An Eames Anthology: Articles, Film Scripts, Interviews, Letters, Notes, Speeches. Yale University Press.

Fujimoto, Sou (2012), El Croquis No. 151 Sou Fujimoto 2003/2010. Primitive Future. Madrid: El Croquis Editorial. Le Corbusier(2007), Toward an Architecture. Getty Publications.

Loos, Adolf (1993), Adolf Loos Escritos II: 1910-1933. Madrid: El Croquis Editorial.

Miralles, Enric and Pinós, Carme (1991), El Croquis no. 49/50, Enric Miralles y Carme Pinós. 1983 1990. Madrid: El Croquis Editorial.

Mulder, Bertus; van Zijl, Ida; Rietveld, Gerrit Thomas (1999), The Rietveld Schroder House. Princeton Architectural Press. Neumeyer, Fritz; Mies Van der Rohe, Ludwig (2000), La palabra sin artificio. Reflexiones sobre arquitectura. Madrid: El Croquis Editorial.

RCR arquitects (2017), El Croquis No. 190 RCR Arquitectes 2012 2017. Madrid: El Croquis Editorial.

RCR arquitects (2007), El Croquis No.138. RCR Arquitectes. Madrid: El Croquis Editorial.

Schulze, Franz; Windhorst, Edward (2019), Ludwig Mies van der Rohe: Una biografía crítica. Reverte.

Tommasi, Giuseppe; Scarpa, Carlo and Guccione, Margherita (2012), Carlo's Scarpa drawings for the Ottolenghi house. Regione del Veneto.

Torres Cueco, Jorge. (2009), Casa por casa: reflexiones sobre el habitar. Memorias culturales. Valencia: TC Cuadernos. Torres Cueco, Jorge (2008), Une maison-Un palais en béton brut. EN BLANCO. Revista de Arquitectura; Vol. 1, Núm. 2 (2008). Valencia: Universitat Politècnica de València. 